\title{
Komenského spisy jako četba žáků základní školy?1
}

\author{
JaRosLaV VALA
}

\begin{abstract}
Abstrakt: Cíle - Studie reaguje na aktuálni diskusi o obsahu a celkovém pojetí literární výchovy na základnich školách. Hlavním cílem je analýza čtenárské recepce osmi odlišných literárnich ukázek žáky devátého ročníku základni školy, následné posouzení rozdílù v jejich čtenár̆ském prijeti a zhodnoceni adekvátnosti pro danou věkovou kategorii čtenárú.

Metody - V kvantitativni části výzkumu jsme použili metodu sémantického diferenciálu a pomoci upravené a faktorovou analýzou ověrené posuzovaci škály jsme zkoumali čtenárské prožitky 203 respondentü z hlediska trí faktorü: srozumitelnosti, hodnoceni a puisobivosti. Kvalitativni ćást šetreni jsme realizovali metodou ohniskových skupin. V pořizených audionahrávkách jsme sledovali, jak žáci vnimali jednotlivé texty a jak nad nimi uvažovali.

Výsledky - Z reakcí žákư vyplývá, že náročný a pro ně nesrozumitelný jazyk znemožňuje sémantické vyznèní některých literárnich dèl objevujicich se v čitankách (J. W. Goethe: Faust, J. A. Komenský: Labyrint světa a ráj srdce). K jeho myšlenkovému poselstvi se pres vlastni text nedostanou. Žáci oceňovali predevšim texty, které jsou schopni vztáhnout ke svému životu i dnešnímu svètu.

Závěry - Výsledky výzkumu mohou sloužit jako základní informace užitečné pro úvahy nad inovaci obsahu výuky i nad jejim posunem smèrem k potrebám a možnostem žákư. Setkávaji-li se žáci s texty $v$ dosahu své úrovně chápáni, můžeme rozvijet i jejich poznatkovou bázi, a to nejen ve vztahu k literárni historii a teorii. Je žádouci a užitečné ovlivňovat čtenárstvi dèti smèrem $k$ vyšš kvalitě. Zároveň však nesmíme ztratit kontakt s jejich bazálním porozuměním, jinak naše výuka ztrati sdèlnost a opravdovost a stane se ryze formální.
\end{abstract}

Klíčová slova: čtenárstvi, recepce textu, porozumèni textu, literárni výchova, čitanka.

Kurikulární dokumenty v České republice (RVP ZV) považují za cíl literárního vzdělávání především rozvoj čtenářských návyků, schopnosti tvořivé recepce, interpretace a produkce literárního textu.
Díky tomu pak mají žáci postupně dospět $\mathrm{k}$ takovým poznatkům a prožitkům, které mohou pozitivně ovlivnit jejich životní postoje i hodnotovou orientaci a obohatit jejich duchovní život. Společně s důrazem

\footnotetext{
${ }^{1}$ Studie vznikla za podpory projektu IGA_PDF_2017_011 s názvem Role uměleckých textů v rozvoji čtenárství na 2. stupni ŽS.
} 
na osvojování poznatků je tedy u literární výchovy zdůrazňována také její esteticko-vzdělávací dimenze a provázání se zkušenostmi žáků.

Navzdory výše uvedené charakteristice literární výchovy v ní ve skutečnosti stále převažuje velmi silné faktografické pojetí, jak potvrzují realizované výzkumy mezi žáky základních škol a gymnázií (Hník, 2014; Radváková, 2015; Vala, 2011). Náplň výuky tvoří stále často frontální výklad, zápis do sešitu a formální krátká četba ukázky, případně mechanická četba dlouhé ukázky, po níž už není čas na další aktivity. Žáci v takové náplni výuky nevidí smysl a takto nabyté vědomosti o autorech a jejich dílech většinou obratem zapomínají. Jedná se o pedagogický formalismus, ve kterém se vzájemně míjejí cíle výuky, její metody i vlastní obsah, jenž by měly představovat zejména adekvátní umělecké literární texty.

Kritika faktografického pojetí výuky neznamená, že bychom měli rezignovat na jakoukoli naukovou složku, která může vést $\mathrm{k}$ hlubšímu vhledu do díla, $\mathrm{k}$ jeho chápání v širších souvislostech i $\mathrm{k}$ rozvoji kulturního rozhledu. Považujeme však za potřebné nabízet ji žákům $\mathrm{v}$ bezprostřední souvislosti $s$ jejich četbou uměleckého textu a jeho reflexí, vést žáky $\mathrm{k}$ aktivnímu poznávání. $\mathrm{K}$ tomu je ideální motivací čtenářský prožitek. Umožňují však žákům texty, s nimiž se setkávají v literární výchově, zažít radost z četby a jejího sdílení? Podporují tyto texty rozvoj čtenářství žáků?

Hlavní náplní učitelovy činnosti v literární výchově by měla být práce $s$ uměleckými texty, které spoluvytvářejí obsah vlastní výuky. Můžeme je považovat za specifický typ učebních úloh, které jsou jedním z faktorů ovlivňujících kvalitu výuky. Prvním předpokladem pro to, aby byla literární výuka smysluplná, je výběr vhodného textu, adekvátního věku, intelektové, osobnostní a emoční zralosti žáků. $\mathrm{Na} 2$. stupni základní školy a v př́slušných ročnících víceletého gymnázia přicházejí žáci $\mathrm{v}$ českých školách poprvé naplno do kontaktu také s literaturou pro dospělé čtenáře. Je otázka, nakolik jim obecně jejich čtenářská vyspělost a osobní zralost dovolují dostat se skutečně ke smyslu těchto textů.

Odpověd' na uvedenou otázku hledáme $\mathrm{v}$ této výzkumné studii, $\mathrm{v}$ níž jsme analyzovali čtenářskou recepci osmi odlišných literárních ukázek žáky devátého ročníku základní školy. Vybrali jsme jak texty z čítanek, které se postupně staly jakýmsi čítankovým kánonem, tak i texty ze současné literatury pro mládež. A sledovali jsme rozdíly $\mathrm{v}$ jejich čtenářském přijetí. Mezi posuzované texty jsme zařadili i čítankovou ukázku z Komenského spisu Labyrint svèta a ráj srdce, na což symbolicky odkazujeme v názvu celé studie.

\section{TEORETICKÁ VÝCHODISKA}

Kritika přežívajícího historismu a důrazu na faktografii se v českém prostředí objevuje průběžně s různou intenzitou a od různých autorů (Hoffman, 2000; Hník, 2014, 2015, 2016; Lomenčík, 2010; Nezkusil, 2004; Vala, 2011). Jenže často se ani oboroví didaktici a učitelé neshodnou 
na jednotném pojetí literární výuky na základní škole. Někteři sice kritizují faktografii, ale obratem dodávají, že probrat se musí to či ono (včetně řady obrozeneckých spisovatelů $s$ různou mírou sdělnosti mladému čtenáři), takže se oklikou $\mathrm{k}$ faktografii znovu dostáváme. Jiní zdůrazňují především čtenářský prožitek a důležitou roli literatury při formování hodnotového systému žáků. Při tomto pojetí se nabízí využití principů tzv. tvořivé expresivity (Slavík et al., 2013), tj. obrazného tvořivého vyjadřování a zprostředkování obsahu, která směřuje žáky $\mathrm{k}$ aktivnímu poznávání i k jejich vlastnímu celostnímu rozvoji.

U žáků základní školy považujeme za zásadní ukázat jim, že čtení je může bavit, že jim může přinést silné emoce i životní poučení; že v něm mohou najít oblasti a témata, která se jich osobně konkrétně dotýkají. Ukázat jim, že čtení může být (a má být) smysluplné. Selže-li tento první a základní krok pro rozvoj čtenářství, selhávají pak i další, sofistikovanější snahy rozvíjet čtenářskou gramotnost, nebot' nemají na čem stavět. Čtenářská gramotnost se totiž prohlubuje a rozvijí v první řadě především vlastním čtenářstvím. A dovednosti získané ve vzdělávacím oboru český jazyk a literatura jsou předpokladem pro kvalitní vzdělávání v dalších (školních i mimoškolních) oblastech.

Oborová didaktika literární výchovy se však v současnosti nachází pod dvojím protikladným tlakem, z něhož každý směřuje $\mathrm{k}$ vyprazdňování obsahu výuky jiným způsobem. Jeden tlak vytváŕí část literárních vědců, kteří upozorňují na postupné zpochybňování a rozmělňování literární- ho kánonu, kladou důraz na tradiční vědomostní výuku a kritizují nové trendy v oblasti literárního vzdělávání (Janoušek, 2015a, 2015b). Přitom ve svých úvahách jednoznačně nerozlišují vzdělání základní, středoškolské a univerzitní. Na druhé straně se mezi některými učiteli a rodiči objevují názory, že je úplně jedno, co děti čtou, hlavně že čtou. Děti jsou pak čtenářsky syceny literaturou nevalné úrovně.

Současné diskuse na toto téma se však odvíjejí pouze z pozice osobního préesvědčení jednotlivých aktérů a nejsou opřeny o výzkumná data, jak a proč žáci čtenářsky prijijímají rozdílné typy textů. Čítanky určené pro žáky 2. stupně ZŠ někdy obsahují ukázky, jejichž hlavním cílem je žáky primárně literárněhistoricky vzdělávat, př́padně $\mathrm{v}$ nich probouzet vlastenecké cítění. Nabízí se otázka, nakolik (a zda vůbec) žáci těmto textům rozumí a jsou schopni z nich pro sebe absorbovat nějaké etické, estetické či obecně kulturní hodnoty. Někdy může pomoci vhodný učitelův prístup, ovšem $\mathrm{v}$ podobných prípadech většinou výuka sklouzává $\mathrm{k}$ předávání faktografických poznatků.

Cílem studie je shrnout a analyzovat výsledky výzkumu, který sledoval žákovskou recepci vybraných textů, tj. čtenáŕskou reakci žáků na dané texty a způsob jejich prijetí. Nesledujeme pouze racionální porozumění, nýbrž i čtenářskou spokojenost a emoci. Porozumění uměleckému textu nevzniká pouze na základě porozumění jeho jednotlivým slovům (Vala, 2015). Chápeme-li umělecké dílo jako zobrazení zážitku v esteticky uspořádaném tvaru (Kulka, 2008), uvědomíme 
si, že k jeho vnímání, pochopení a přijetí nestačí pouze rozum.

\subsection{Výběr literárního textu}

$\mathrm{V}$ teoretické rovině směřujeme naší studií do oblasti výzkumu kvality výuky z pohledu oborových didaktik. Za podstatné považujeme propojení obsahu výuky $s$ jejími cíli a použitými metodami, $\mathrm{k}$ němuž v literární výchově často nedochází. Vycházíme z modelu hloubkové struktury výuky (Slavík et al., 2014), který zdůrazňuje potřebu práce se žákovskými prekoncepty, tj. dosavadními zkušenostmi, znalostmi a představami (blíže viz Škoda, Doulík et al., 2010). Pracujeme-li v literární výchově $s$ velkým množstvím různých typů textů, měli bychom se zajímat o to, jak tyto texty navazují na čtenářské prekoncepty žáků. Př́padně jaký nabízejí potenciál dalšího rozvoje jejich čtenárství.

Cílený výběr vhodných uměleckých textů určených $\mathrm{k}$ četbě a didaktické interpretaci, podobně jako volba vhodných metod, má zásadní vliv na míru efektivity a kvality dané výuky. Hlubší vhled do recepčního procesu a zjištění konkrétních čtenářských preferencí umožňuje volbu jak adekvátnějších textů, tak také metod výuky.

Zahraniční výzkumy týkající se čtenářství a podpory jeho rozvoje se soustředí na preferenci oblíbených titulů, na rozdíly mezi chlapci a dívkami, na místo čtenářství mezi volnočasovými aktivitami, způsob výběru titulů apod. (Manuel \& Carter, 2015; Hopper, 2005; Uusen, 2010; Uusen \& Müürsepp, 2012). Méně pozor- nosti je věnováno konkrétním typům textů, $s$ nimiž se žáci ve výuce setkávají. Jones (2003) se zabývá problémy se čtením u náctiletých chlapců v USA a navrhuje strategie, jak je motivovat $k$ četbě. Doporučuje především zabývat se kratšími texty, které jsou pro chlapce zajímavé svým tématem. Mezi ně řadí různé mytologie, hororové povídky, knihy o autech a elektronice, poezii a ř́kanky s hlavolamy, biografie známých osobností. Watkinsonová a Aimonette Liangová (2014) řeší současnou podobu učebnic anglického jazyka a literatury v USA na základě proporce žánrů fikce a literatury faktu a konstatují, že tyto učebnice obsahují až nadmíru uměleckých textů vzhledem k ostatním druhům literatury.

Specifický odborný zájem věnují výzkumníci práci s poezií, která činí učitelùm i žákům velké potíže svou nejednoznačností, a ukazují, jak s ní pracovat: metoda hlasitého myšlení (Ewa-Wood, 2008), rozvíjení kreativity žáků (Hennessy \& McNamara, 2011), poetické kroužky (Young, 2007). Peskin, Allen a Wells-Jopling (2010) se systematicky věnují schopnosti žáků interpretovat symboliku v poezii. Edgington (2002) poukazuje na důležitost hodnotové výchovy v rámci školy a na důležitou roli literárního vzdělávání v této oblasti.

Některé výše uvedené studie chtějí čelit menšímu zájmu dětí o čtení výběrem kratších ukázek, hororů, medailonů populárních lidí. Postrádáme analýzu toho, jak konkrétně žáci reagují na vhodně zvolené ukázky z umělecké literatury, která se nepodbízí, a naopak má potenciál př́stupně čtenáře rozvíjet. 


\section{Metodologie A PRŮBĚH VÝZKUMNÉHO ŠETŘENÍ}

Hlavním cílem výzkumu byla analýza čtenářské adekvátnosti literárních textů z pohledu žáků základní školy.

Realizovali jsme celkem tři výzkumná šetření mezi 610 žáky 7.-9. ročníků se třemi sadami literárních ukázek, které byly vždy vybrány zčásti z čítanek pro daný ročník a zčásti z umělecké literatury určené pro mládež, prrípadně pro dospělé čtenáře. Každá sada obsahovala osm ukázek.

Ve studii představujeme výsledky té části výzkumu, kterou jsme realizovali mezi žáky 9. ročníků a př́ślušných ročníků víceletého gymnázia. Šetření se zúčastnilo celkem 203 respondentů. Sledovali a analyzovali jsme jejich čtenářskou reakci na vybrané ukázky, abychom zjistili jejich čtenářské preference a hlouběji nahlédli do jejich uvažování nad uměleckou literaturou. Zároveň jsme se soustředili na rozdíly ve vnímání textu mezi jednotlivými kategoriemi respondentů: podle pohlaví, prospěchu, vztahu k četbě, vztahu $\mathrm{k}$ literární výchově apod.

V kvantitativní části výzkumu jsme použili metodu sémantického diferenciálu (SD) a pomocí upravené a faktorovou analýzou ověřené posuzovací škály jsme zkoumali čtenářské prožitky respondentů $\mathrm{z}$ hlediska tř́ faktorů: srozumitelnosti, hodnocení a působivosti (Vala, 2011).

Kromě zachycení čtenářských prožitků kvantitativní výzkumnou metodou jsme použili také metodu ohniskové skupiny. Jedná se o rozhovor založený na sku- pinové interakci, díky níž může metoda generovat neotřelé pohledy na dané téma, odhalovat nové vztahy mezi jevy a ukazovat dosud nezaznamenané kontexty (Morgan, 1996). Specifikum ohniskových skupin tkví v nízkém zapojení výzkumníka, který vystupuje $\mathrm{v}$ roli moderátora, a ve vysoké aktivitě respondentů, kteří se účastní otevřeného rozhovoru na výzkumníkem dané téma. $\mathrm{V}$ pořízených audionahrávkách jsme sledovali, jak žáci vnímali jednotlivé texty a jak nad nimi uvažovali. Zajímalo nás, jak se jim tyto ukázky četly a jaké sdělení $\mathrm{v}$ nich našli; zda by byli ochotni si prečíst celou knihu a zda tento typ textů podle nich patři do čítanek pro jejich věkovou kategorii. $\mathrm{V}$ představované části výzkumu se nahrávek zúčastnilo 15 žáků ze dvou škol, kteř́ byli rozděleni do tří skupin.

Žáci byli se smyslem a průběhem nahrávání předem seznámeni. $S$ předstihem měli k dispozici i posuzované texty. Moderátorka rozhovoru vždy položila jednu otázku a dávala dětem prostor $\mathrm{k}$ odpovědím i $\mathrm{k}$ vzájemným reakcím. Naše úsilí však bylo limitováno do jisté míry omezenou schopností žáků mluvit o textech a samostatně sdělovat své myšlenky a pocity. Tento př́stup $\mathrm{k}$ literární výuce, založený na oboustranně otevřené a respektující komunikaci, není v našich školách bohužel príiliš rozšiřrený a žáci na něj nejsou zvyklí.

Při kombinaci obou metod jsme zvolili sekvenční př́stup: kvantitativní výzkum nám kromě výsledných dat přinesl i další otázky, na něž jsme hledali odpověd' v kvalitativní linii výzkumu. 


\subsection{Způsob zpracování výsledků}

Každý respondent vyplňoval ke každému textu 18 škál, prvních šest se týkalo srozumitelnosti, dalších šest hodnocení a posledních šest působivosti (tab. 1). Škály byly uspořádány reverzně, aby nedocházelo $\mathrm{k}$ jejich mechanickému vyplnění.

U získaných dat jsme faktorovou analýzou (metoda hlavních komponent, varimax normalizovaný) ověřovali faktorovou identitu škál. Prokázali jsme, že jednotlivé škály jsou dostatečně syceny očekávaným faktorovým nábojem (tab. 2). Sledované faktory objasňují přibližně $72 \%$ celkového rozptylu. Reliabilitu měřní jsme ověřovali Cronbachovým koeficientem alfa, celkové výsledky pro všech osm textů dosáhly ve třech sledovaných faktorech hodnot: $\mathrm{S}=0,92 ; \mathrm{H}=0,94 ; \mathrm{P}=0,88$.

Při vlastním zpracování výsledků jsme pro každého respondenta spočítali prostý aritmetický průměr pro každý faktor, čímž jsme získali jednu hodnotu pro každý ze tři hodnocených aspektů textu. Rozdíly mezi vnímáním jednotlivých textů jsme zachytili pomocí krabicových grafü - boxplotů (viz obr. 1). Pro testování rozdílů

Tab. 1. Sémantický diferenciál pro sledování čtenářské recepce

srozumitelná

komplikovaná

nechápu

nejasná

odkrytá

průhledná

líbí

nečetl bych ji znovu

špatná

ošklivá

přitahuje mě

př́ijemná
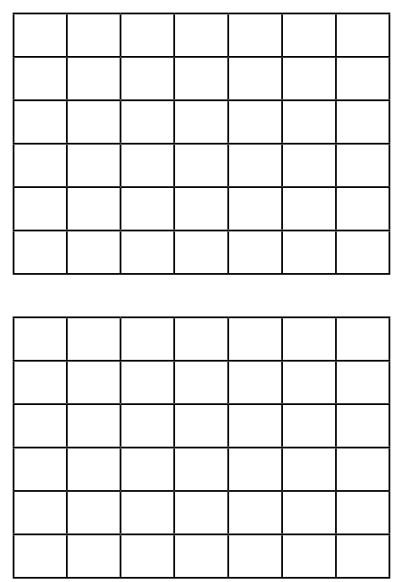

slabá

hluboká

ostrá

malá

účinná

mocná nesrozumitelná

jednoduchá

chápu

jasná

skrytá

neprůhledná

nelíbí

četl bych ji znovu

dobrá

krásná

nepřitahuje mě

nepříjemná

silná

mělká

tupá

velká

neúčinná

bezmocná 
Tab. 2. Výsledky faktorové analýzy (faktorové náboje)

\begin{tabular}{|c|c|c|c|}
\hline \multirow[t]{2}{*}{ Škála } & \multicolumn{3}{|c|}{$\begin{array}{c}\text { Extrakce: Hlavní komponenty } \\
\text { Rotace: Varimax normalizovaný } \\
\text { Označené faktorové náboje jsou > } 0,70\end{array}$} \\
\hline & $\begin{array}{c}\text { Faktor } 1 \\
\text { Srozumitelnost } \\
\end{array}$ & $\begin{array}{c}\text { Faktor } 2 \\
\text { Působivost } \\
\end{array}$ & $\begin{array}{c}\text { Faktor } 3 \\
\text { Hodnocení }\end{array}$ \\
\hline 1 & 0,775118 & 0,152756 & 0,378008 \\
\hline 2 & 0,807410 & 0,018296 & 0,265904 \\
\hline 3 & 0,774531 & 0,152432 & 0,381451 \\
\hline 4 & 0,804840 & 0,159490 & 0,346089 \\
\hline 5 & 0,818474 & 0,084881 & 0,121167 \\
\hline 6 & 0,768609 & 0,032235 & 0,183652 \\
\hline 7 & 0,425797 & 0,327465 & 0,736508 \\
\hline 8 & 0,329339 & 0,301915 & 0,728470 \\
\hline 9 & 0,381065 & 0,318831 & 0,750143 \\
\hline 10 & 0,234511 & 0,232204 & 0,791626 \\
\hline 11 & 0,304054 & 0,339520 & 0,755384 \\
\hline 12 & 0,294026 & 0,152379 & 0,765671 \\
\hline 13 & 0,071194 & 0,790637 & 0,229837 \\
\hline 14 & $-0,027430$ & 0,816985 & 0,136685 \\
\hline 15 & 0,148294 & 0,771661 & 0,121038 \\
\hline 16 & 0,064317 & 0,789423 & 0,149212 \\
\hline 17 & 0,192506 & 0,715132 & 0,408556 \\
\hline 18 & 0,141241 & 0,706491 & 0,387166 \\
\hline Expl. Var. & 4,518871 & 4,094800 & 4,371879 \\
\hline Prp. Totl. & 0,251048 & 0,227489 & 0,242882 \\
\hline
\end{tabular}

Expl. Var. - rozptyl (variance), který je daným faktorem vysvětlován; Prp. Totl. - informuje o tom, jakou část (kolik procent) celkového rozptylu daný faktor objasñuje

mezi jednotlivými skupinami respondentů jsme použili Kruskalův-Wallisův test, který představuje neparametrickou verzi klasického testu ANOVA. Testovali jsme hypotézu, že náhodné výběry v jednotlivých skupinách pocházejí ze stejného rozdělení proti alternativě a že alespoň jeden výběr pochází z jiného rozdělení.

\section{VÝSLEDKY}

Nejprve se seznámíme s charakteristikou jednotlivých ukázek a s výsledky jejich čtenářského přijetí ze strany žáků. Tyto údaje pak doplníme informacemi z nahrávek žákovských diskusí nad těmito texty. Zaměřovali jsme se $\mathrm{v}$ nich na to, 
jak žáci ukázkám rozumí, zda se jim líbí a zda mají potenciál rozvíjet jejich čtenářství.

\subsection{Like me: každé kliknutí se počítá (T. Fiebel)}

Ukázka zachycuje situaci, kdy se dvě kamarádky dohadují, které z nich mají patřit body/lajky za zveřejněné video $s$ opilými učiteli (do nealkoholického punče jim žáci přidali alkohol). Týká se aktuální problematiky sociálních sítí a jejich vlivu na mezilidské vztahy. Samotná ukázka sugeruje napětí, využívá proměnlivé tempo řeči či projevu, je psána ich-formou, takže zvýrazňuje možnosti konkretizace prožitku a vlastní zkušenosti, umožňuje nahlédnout do myšlení a cítění dítěte.

Žáci reagovali po přečtení ukázky pozitivně: oceňovali, že zobrazuje jejich vrstevníky a jim blízký svět. Zároveň mají dojem, že literární postavy zašly ve svém jednání až př́iliš daleko. Při úvahách nad myšlenkovým vyzněním textu někteří žáci uváděli, že se postavy chtěly zviditelnit za každou cenu. Někteř́ žáci uvažovali nad smyslem textu podrobněji a přesněji:

Tereza: A taky že hlavně bylo dìležitý pro ten jeji żivot, na kolikátým misté bude na té sociálni siti, i když v opravdovém životé treba ty kamarády ani neměla. A blavně že méla ty virtuálni kamarády nebo ríkala tam, že nebudu sama. Mám spoustu prátel na té sociálni siti.

Přestože je celková estetická úroveň tohoto textu sporná, přináší aktuální zajímavé a závažné téma, se kterým se dá v literární výchově podnětně pracovat. A má potenciál rozvíjet dětské čtenářství i směrem $\mathrm{k}$ umělečtějším textům. Žáci uváděli, že by si rádi knihu přečetli. A shodli se, že by v čítankách uvítali ukázky z novějších děl, která se týkají aktuálních problémů mládeže.

\subsection{Labyrint světa a ráj srdce (J. A. Komenský)}

Poutník se vydává poznávat svět. Ukázka zachycuje jeho seznámení se Všudybudem a Mámením, kteří jej na jeho pouti doprovázejí. Nasazují poutníkovi uzdu všetečnosti a brýle mámení, které ukazují svět opačný, než jaký je ve skutečnosti.

V ukázce vybrané z čítanky pro 9. ročník ZŠ je čtenár konfrontován s jazykovou i uměleckou realitou starou čtyři stovky let. Žáci nebyli téměř schopni o ukázce hovořit, natolik pro ně byla nesrozumitelná. Všichni konstatovali, že se jim ukázka četla špatně; někteří uváděli, že jim nepomohlo ani opakované čtení. Jako důvod označují archaismy, nesrozumitelná spojování vět apod. Někteří uvádějí, že nad myšlenkou textu kvůli jeho náročnosti ani nepřemýšleli:

Kačka: Protože takble akorát premýślim nad tím, co vlastně $v$ té vètě chtěji asi ríct, abych tu vètu vỉbec poskládala a zjistila, kde je konec a kde začíná vèta.

Danča: Jo (myšlenku jsem hledala), akorát to se nedá, když tomu člověk nerozumi, a tak...

Tereza: Je to hodnè obtižný tomu porozumèt, protože ten jazyk je preci jen jiný. Skoro jsem si pripadala, jako bych to četla $v$ jiným, cizim jazyku, kterému zas tak moc nerozumím. 
Žáci uvádějí, že by si knihu, z níž byla ukázka vybrána, sami nepřečetli. Jde o typ ukázky, která je nevhodná pro danou věkovou kategorii. Její výběr a zařazení do čítanek pro základní školu nejenže nepodporuje a nerozvíjí dětské čtenářství, ale prrímo od něj odrazuje. Navíc práce s tímto textem na základní škole jde prímo proti duchu Komenského pedagogických zásad zdůrazñujících přiměřenost učiva věku a zralosti žáků.

\subsection{Já jsem Malála (Malála Júsufzajová)}

Ukázka zachycuje terorismus z pohledu civilistů, konkrétně mladé dívky. Čtenáŕi poskytuje nejen definici terorismu na základě vlastních prožitků, ale také nahlédnutí do života lidí, kteří se bojí každý den nejen o svou živnost, obydlí, ale i o život svůj a svých blízkých. Autorka lící, čeho všeho se lidé v jejím okolí pro vlastní bezpečí museli vzdát.

Hlavním poselstvím věcného a strohého textu je autenticita prožívaného strachu a popis situace, jíž dominuje skryté, neidentifikovatelné a nepostižitelné zlo. Je nepochybné, že děti žijící v permanentním ohrožení a strachu jsou výrazně vnímavější ke svému okolí, rychleji dospívají, jsou vyzrálejší apod. Tento výrazný rozdíl ve srovnání s dětmi evropskými nesouvisí jen $s$ přestátým utrpením a pocitem ohrožení, ale také $s$ kulturními odlišnostmi a náboženskou tradicí.

Zajímalo nás, nakolik budou žáci vnímaví vưči této problematice a zda považují knihu za vhodnou pro svoji věkovou kategorii.
Z jejich reakcí vyplývá, že ukázka se většině $\mathrm{z}$ nich líbila. Zdůrazňují tragiku celé situace, její aktuálnost i napětí ( $J a ́$ mám ráda takové ty o svèté, co se tréeba stalo. Mám ráda, když je to takový tragický, drama. Mě to bavi císt, protože mě zajímá, co bylo.). Klíčová slova, kterými charakterizovali svůj hlavní pocit z ukázky, byla nejčastěji soucit a lítost. Někteří byli ukázkou šokovaní, nechápali, jak může jejich vrstevnice prožívat takové věci. Byli tedy schopni vztáhnout text ukázky jak ke svému životu, tak i ke světu kolem sebe.

Kája: Tak jako na to, jak je mladá, tak piše velmi dobře. Jako srozumitelnè. Kolikrát procházim blogy a holky písou, je jim osmnáct a neni to ani z puilky tak srozumitelné. Dokázala koncentrovat i své vzpominky takhle dobre.

Většina žáků by souhlasila $s$ tím, aby ukázka $\mathrm{z}$ této knihy byla $\mathrm{v}$ ćítankách pro jejich věkovou kategorii. Pouze jedna dívka reagovala váhavě s tím, že si není jistá, jak by četbu zvládly slabší povahy. Dưvody, proč ukázku z této knihy zařadit do čítanek, vystihla nejlépe Tereza.

Tereza: Já si naopak myslim, že by se to mèlo zařadit, protože bysme taky mèli možná védèt, co se děje okolo nás a ne jenom nějaké historické texty, ale taky i nèjaké aktuální texty. Takže se třeba často mluvi o uprchlicich a tady vidime vlastně ty divvody, proč třeba musi uprchnout nebo tak.

\subsection{Faust (J. W. Goethe)}

Ukázka líčí, jak dábel svádí Fausta a nabízí mu mládí a úspěch, peníze a radosti života; na oplátku žádá úpis pode- 
psaný Faustovou krví. Poslední část ukázky je výňatkem závěrečné scény a Faustova prožrení.

Ukázka je vybrána z čítanky pro 9. ročník ZŠ. Zajímalo nás, nakolik je tento text srozumitelný dnešním mladým čtenářům. A nakolik oprávněné je jeho zařazení $\mathrm{v}$ této čítance.

Někteři žáci se už s faustovskou tematickou setkali dř́ve, což ovlivňuje jejich vnímání tohoto textu. $\mathrm{Na}$ otázku, jak se jim ukázka z Fausta četla, reagovali vesměs jednoznačně:

Lucka: Vübec. Nebavil mé čist, paskvil.

Nella: Hroznè. Já jsem prostě, úplně... Já jsem prečetla celou stránku a vỉbec jsem nevédèla, o čem jsem četla.

Kačka: Jako dèj dobrej, ale kdyby to bylo napsaný lip.

Naty: Ne, ale mě právě že... Mě se to taky nelibi, ale práve že, když je to v té básničce, tak je to takový lepší, že kdyby to bylo $v$ plynulém textu, tak se to nedalo viobec císt.

\section{David: Chaotické.}

Vojta M.: Mně se to moc nelibi, já si to nedokáżu predstavit. Tam neni vủbec popsaný, co tam u toho dělaji a takové véci.

Mája: No právě, že já jsem tam žádný děj nějak nenašla.

Ajja: Nevím, mnè se to prostè blbè čte. Jsou tam cizi slova.

$\mathrm{Z}$ uvedených odpovědí je patrné, že někteří žáci měli skutečný problém $s$ pouhým porozuměním textu (porozuměním slovům, větám), takže se nedostali ani $\mathrm{k}$ základním myšlenkám. Jen výjimečně se k ukázce vyjadřují pozitivněji, a to zejména $\mathrm{v}$ prrípadě, že se s danou tematikou setkali i v jiné podobě. Pouze jediné žákyni, kte- rou její učitel považuje za jednu z nejaktivnějších z celé trrídy, se podařilo zformulovat svoji myšlenku jasněji ve smyslu, že Faust poznal, co je pravým smyslem života, že vlastně umřel štastný. Smysl života viděl $\mathrm{v}$ trvalých hodnotách, v tom, co může udělat pro ostatní.

Podle reakcí žáků na text i podle jejich explicitních vyjádření není Goethův Faust literární dílo, které by mělo potenciál je aktuálně zaujmout a přivést $\mathrm{k}$ četbě. Ukázka patřila mezi nejhưře hodnocené texty.

\subsection{Hrdý Budžes (Irena Dousková)}

Hlavní protagonistka Helča začala chodit do jiskřiček a popisuje první společný výlet. Najde prasečí kost, o níž je nejprve přesvědčena, že patři partyzánovi. Ukázku jsme vybrali z čítanky pro 9. ročník ZŠ. Autorka v ní představila svou životní zkušenost čtivě, hravě a s přirozeným smyslem pro napětí. Celé líčení směřuje $\mathrm{k}$ ironizování předkládané skutečnosti, což představuje vyšší úroveň porozumění, k níž je obtížné se dostat bez znalosti historického kontextu.

Žáci oceňovali především srozumitelnost jazyka, zejména ve srovnání s jinými posuzovanými texty, a zábavnost textu. Jen výjimečně byli schopni přesněji pojmenovat hlavní intenci textu:

Kája: No já si zase myslím, ne jak ríkala Markétka, já jsem totiž četla celou knižku. Že je to prostě zjednodušenej pobled toho dítète na to obdobi té okupace... Ona prostè, všechny dèti chodi na Jiskričky a takovýhle ty véci a ona chodí jenom na nèmčinu, proto- 
že ta jeji maminka komunisty nemá ráda. A ona pak méla i těžký život.

Někteři žáci by si knihu přečetli a zařadili ukázku do čítanek:

Markéta: Tak pro devitky, zbytek ani neví, co to druhá svétová válka je.

\subsection{On je fakt boží! (Louise Rennison)}

Čtrnáctiletá Georgia prožívá všechny obtíže dospívání. Přehnaně dbá o svůj vzhled, avšak neúspěšný pokus o úpravu obočí končí z jejího pohledu katastrofálně. Tento dívčí román můžeme zařadit spíše do triviální literatury. Zajímalo nás, jak ji budou vnímat žáci v kontextu ostatních ukázek a jaký postoj budou mít $\mathrm{k}$ této dívčí tematice chlapci.

Většina $\mathrm{z}$ dívek viděla stejnojmenný film, což ovlivnilo jejich posuzování textu. Jiné knihu četly a považují ji za oddechové čtení (Je dobrá na prázdniny, když nemám o čem premýšlet.). Zároveň poukazují na obtížné rodinné prostředí hrdinky a srovnávají to se svou situací.

Mája: Mně spiš prijjde, ž to má doma takový trošku těžši. Že když tam po ní řvou, že nèco udělala, tak mně by se tréba naši smáli a délali si ze mé srandu, než aby po mné rvali...

Chlapci film neznali, knihu by nečetli, ale oceňují na ní, že je aktuální, že je z dnešní doby. Ukázku by zařadili do čítanek pro základní školu, důvody vyjádříli velmi stručně:

Vojta M.: Protože se to dobře čte.

Mája: A taky je $z$ toho denniho života té holky.

Danča: Trošku se podobá nám všem.

\subsection{Filozofská historie (Alois Jirásek)}

Děj ukázky se odehrává na vysokoškolské přednášce na konci 19. století. Studenti se bouří proti zrušení majálesu. Ukázka byla vybrána z čítanky pro 9. ročník ZŠ. Zajímalo nás, zda je ukázka pro dnešní žáky sdělná a téma aktuální.

Zjistili jsme, že ukázka se jim nelíbila, nezajímala je, nemají zájem si tuto knihu přečíst. $Z$ jejich dalších výpovědí vyplývá, že jim připadala vytržená z kontextu, nesrozumitelná:

Nella: ... já ji prečetla a vỉbec jsem nevédèla, co jsem četla.

Kája: Já nevím, kdyby tam byla návaznost, hlavni myšlenka, která se rozvijela od začátku. Ale takble mi prìjde, že prosté vytržený z kontextu. Jako jo, člověk se chytí, ale nevi, co bylo pred tím.

Studentské bouře v 19. století související se zakázaným majálesem nepředstavují pro dnešní žáky dostatečně zajímavé a aktuální téma.

\subsection{Zlodějka knih (Marcus Zusak)}

Děj se odehrává za druhé světové války v Německu. Personifikovaná smrt sleduje umírajícího anglického pilota a čeká na jeho duši, aby ji mohla doprovodit na poslední cestě. Román reprezentoval v našem výběru typ současných knih, které jsou čtivé, srozumitelné, ale zároveň nesou silnou myšlenku, silné poselství.

$\mathrm{Z}$ přepisu nahrávek vyplynulo, že žáky ukázka zaujala a vedla je k přemýš- 
lení. Hlavní emoce, kterou pocitovali, byl smutek a dojetí. Uvědomovali si tíživost tehdejší doby: Vidim, že to v té době muselo být těžký. I Ulevilo se mi, že to mám prečtený.

Na rozdíl od jiných ukázek zařazených do výzkumu se žáci k tomuto textu vyjadřovali spontánně, mluvili v delších větách, jejich rozhovor probíhal celkově plynuleji. Většina žáků by měla chut si přečíst celou knihu. A doporučili by její zařazení do čítanek. Oceňovali závažnost tématu i myšlenkovou náročnost, které však byly podány srozumitelným a působivým způsobem:

Tereza: Je tak hodně k zamyšlení, ale takovou srozumitelnèjš formou než třeba tam ten Labyrint svèta a ráj srdce, nebo co to bylo.

\subsection{Srovnání výsledků recepce všech textů}

Porovnání výsledků čtenářského přijetí posuzovaných textů přináší graf 1 . Tečka zachycuje medián hodnot, silná čára (box) vede od 25\% kvantilu k $75 \%$ kvantilu a tenké čáry ukazují celkový rozsah dat. Čím je silná čára (box) kratší, tím více se respondenti (např́č kategoriemi) shodovali ve vnímání daného textu. Je to patrné především u všech faktorů u textu T3 (Já jsem Malála). Naopak delší silná čára značí širší rozpětí žákovských odpovědí, tj. jejich menší shodu. Velmi výrazný je tento výsledek např. ve faktoru hodnocení u textu T6 (On je fakt božzi.), kde jsme zjistili extrémní rozdíly v posouzení textu mezi chlapci a dívkami, jejichž hodnocení bylo výrazně pozitivnější.
Pro snazší orientaci v následujícím grafu znovu uvádíme autory a názvy jednotlivých posuzovaných textů:

Text 1 Like me: každé kliknutí se počitá (T. Fiebel)

Text 2 Labyrint svèta a ráj srdce (J. A. Komenský)

Text 3 Já jsem Malála (Malála Júsufzajová)

Text 4 Faust (J. W. Goethe)

Text 5 Hrdý Budžes (I. Dousková)

Text 6 On je fakt boži! (Louise Rennison)

Text 7 Filozofská historie (A. Jirásek)

Text 8 Zlodéjka knih (Marcus Zusak)

\section{DisKuSE VÝSLEDKU゚}

Mezi nejhůře posuzovanými ukázkami z hlediska faktoru hodnocení, který nejlépe ukazuje čtenářskou přitažlivost textu, najdeme tři texty (T2, T4 a T7) vybrané z čítanky pro 9. ročník. Dva z nich jsou pro žáky velmi nesrozumitelné (Labyrint svèta a ráj srdce a Faust). Jedná se sice o texty v českém jazyce, takže recipienti většinou rozumí jednotlivým slovům, avšak na úrovni slovních spojení v textu a jejich vzájemných vztahů ztrácejí orientaci. Můžeme tedy konstatovat, že žáci nepřekonali tzv. povrchovou strukturu textu a nebyli schopni se dostat $\mathrm{k}$ jeho sémantickému obsahu. Svoji roli zde hraje archaický jazyk (Komenský), př́padně antikvovaný překlad (Faust). Jiráskův text je ve srovnání s nimi vnímán jako srozumitelnější, avšak jeho téma žáky nezajímalo, respektive nenašli jeho smysl. Lepší výsledky získaly tyto texty (zejména T2 a T4) ve faktoru působivosti. Z komentárů žáků vyplývá, že vzhledem $\mathrm{k}$ nesrozumitelnosti těchto textů 


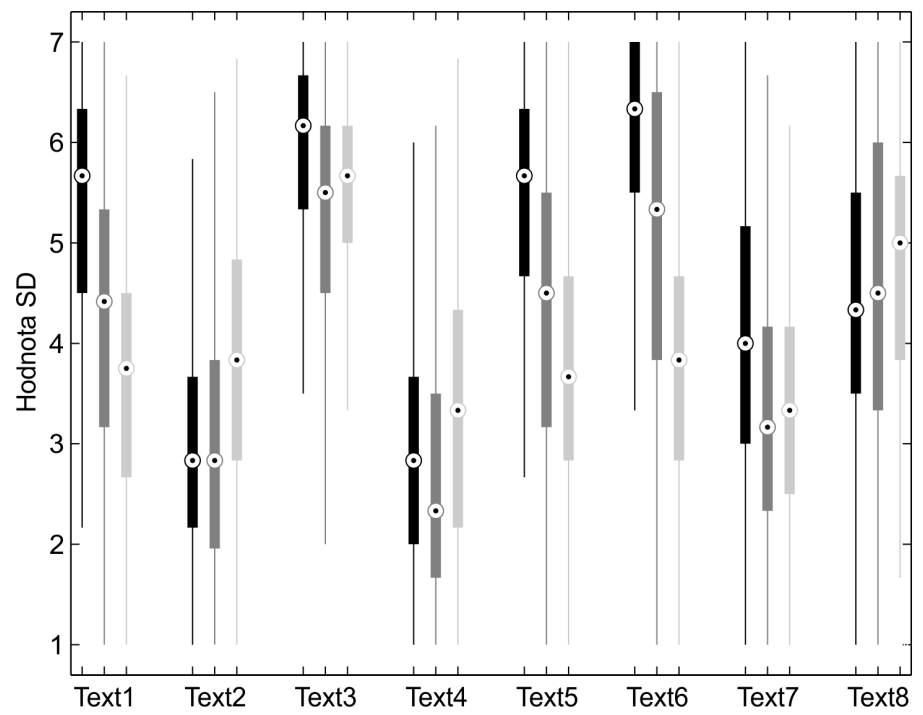

srozumitelnost

hodnocení působivost

Obr. 1. Grafické znázornění výsledků recepce všech textů

jim přisuzují velké myšlenky a čtenářskou náročnost (... asi tam nějaká myšlenka je), př́padně o nich již ve škole slyšeli.

Dva texty (T1 a T6) reprezentovaly současnou zábavnou literaturu pro mládež. Podobné knihy mají potenciál přivést žáky ke čtení, které pak můžeme dále kultivovat. Děti oceňovaly, že těmto ukázkám rozuměly: z pohledu doby, témat, jazyka, postav, prostředí apod. Je to přirozené, nebot čteme proto, abychom se něco dozvěděli o světě i o sobě, abychom na přečtených knihách vnitřně rostli.

Žáci zároveň prokázali dostatečnou senzitivitu i při četbě textů umělecky hodnotnějších (T5 a T8) ve srovnání se zmiňovanou zábavnou literaturou. Především jejich čtenářské reakce na román Zlodějka knih ukazují, že i náročnější literatura určená dospělým čtenářům je dokáže zaujmout, zobrazuje-li pro ně pochopitelné téma dostatečně srozumitelně.

Nejpozitivněǰ̌sí bylo čtenářské přijetí ukázky z románu Já jsem Malála (T3). Výsledky $\mathrm{SD} u$ všech faktorů byly obdobně vysoké a výjimečně vyrovnané, tj. text zaujal čtenáře různými svými aspekty. A především z hlediska emocionální působivosti neměl tento text mezi ostatními srovnatelnou konkurenci. Představuje typ textu, který pomáhá žákům porozumět současnému světu: jeho rozmanitosti i nepochopitelným krutostem. Je-li autorkou jejich vrstevnice, dostává celý text pro žáky ještě intenzivnější nádech. Považujeme za vhodné pracovat $s$ podobnými texty, které mají pro žáky zřetelný vztah $\mathrm{k}$ dnešnímu světu i jejich životu, a vést děti na jejich základě k uvažování 
$\mathrm{v}$ širších souvislostech. Mohou se zařazovat do výuky $\mathrm{v}$ jiných predmětech (občanská výchova a dějepis), a posilovat tak mezipředmětové vztahy a myšlenkové spojitosti.

\section{ZÁVĚR}

Z reakcí žáků vyplývá, že náročný a pro ně nesrozumitelný jazyk díla znemožňuje sémantické vyznění díla. K jeho myšlenkovému poselství se přes vlastní text nedostanou. Totéž platí o textech s nesrozumitelnými tématy. Žáci oceňovali především texty, které jsou schopni vztáhnout ke svému životu i dnešnímu světu. V tomto prokazují nezvykle velkou citlivost (viz jejich reakce na text 3). To samozrejmě umožňuje i řada děl klasické literatury, jen je třeba vždy zvažovat adekvátnost daného textu zralosti žáků i jeho aktuální sdělnost. Bez toho se starší literatura může žákům jevit mrtvá. A pokud vůbec po hodině literární výchovy v jejich paměti utkví J. A. Komenský, tak zejména jako ten, kdo psal ty nesrozumitelné texty.

Naprosto nejde o zpochybnění uměleckých a myšlenkových kvalit řady těchto děl. Jde o přijetí skutečnosti, že některá z nich nejsou dostatečně čtenářsky př́stupná ani mnoha dospělým čtenářům, natož dětem.

Setkávají-li se žáci $s$ texty $\mathrm{v}$ dosahu své úrovně chápání, můžeme rozvíjet i jejich poznatkovou bázi, a to nejen ve vztahu k literární historii a teorii. Jde zároveň a především o vztah $k$ naší současnosti, text dětem musí říkat něco o nich, o nás, o naší době. A to i prostřednictvím různých historických událostí $s$ přesahem do dneška. Takový prrístup klade značné nároky na učitele, na jejich schopnost propojovat minulost a současnost, hledat a vidět nové vazby, které aktualizují starší texty.
Výzkum mimo jiné ukázal, že žáci nejsou zvyklí vyjadřovat se o textech, které čtou. Nejsou zvyklí nad nimi sami přemýšlet a formulovat svoje myšlenky a pocity. Domníváme se, že je důležité žáky učit mluvit, sdílet prožitky tak, aby to bylo srozumitelné druhým. Není to jednoduché, vyžaduje to u žáků určitou míru introspekce a abstraktního myšlení, ale je to směr, kterým by se měla literární výchova vydat. Navzdory některým hlasům vyjadřujícím se $s$ despektem o důrazu na komunikaci a prožitek v literární výchově.

S žákovskými prekoncepty čtení je třeba pracovat uváženě: některé rozvíjet, jiné měnit, posouvat dál. Pokud se však o ně vůbec nezajímáme a naplňujeme obsah výuky bez jejich alespoň částečného uvědomění si, může se stát, že se náhle nebudeme mít o co opřít. Domnělá stavba vědomostí bude jen iluzí bez reálných základů. A celá výuka bude mít podobu předstírání ve vztahu $\mathrm{k}$ žákům a sebeklamu ve vztahu k sobě jako učitelům. Jako bychom společně se zmiňovaným Komenského poutníkem měli nasazené brýle mámení bránící nám ve vnímání reality.

Výsledky představeného výzkumu mohou sloužit jako základní informace užitečné pro úvahy nad inovací obsahu výuky i nad jejím posunem směrem $\mathrm{k}$ potřebám a možnostem žáků. Přemýšlejme nad tím, co a jak dělat $\mathrm{v}$ literární výchově jinak, aby se žáci setkávali s takovou četbou, $s$ jejiž pomocí se mohou osobnostně rozvíjet a růst. Je žádoucí a užitečné ovlivňovat čtenářství dětí směrem $\mathrm{k}$ vyšší kvalitě. Zároveň však přitom nesmíme ztratit kontakt $s$ jejich bazálním porozuměním, jinak naše výuka ztratí jakoukoli sdělnost a opravdovost a stane se ryze formální. 


\section{LiTERATURA}

Edgington, W. D. (2002). To promote character education, use literature for children and adolescents. The Social Studies, 93(3), 113-116.

Ewa-Wood, A. L. (2008). Does feeling come first? How poetry can help readers broaden their understanding of metacognition. Journal of Adolescent \& Adult Literacy, 51(7), 564-576.

Hennessy, J., \& McNamara, P. M. (2011). Packaging poetry? Pupils' perspectives of their learning experience within the post-primary poetry classroom. English in Education, 45(3), 206-223.

Hník, O. (2014). Didaktika literatury: výzvy oboru. Praha: Karolinum.

Hník, O. (2015) Školní literární kánon. Český jazyk a literatura, 66(5), 234-241.

Hník, O. (2016) K problému kvantity poznatků v literární výchově. Český jazyk a literatura, $67(2), 83-87$.

Hoffmann, B. (2000). Literatura a škola na prahu třetího tisíciletí. Český jazyk a literatura, 50(7-8), 187-192.

Hopper, R. (2005). What are teenagers reading? Adolescent fiction reading habits and reading choice. Literacy, 11, 113-120.

Janoušek, P. (2015a). S kanónem na kánon aneb Kvadratura kánonu a nesamozřejmost jeho samožrejmosti I. Tvar, 16, 11-12.

Janoušek, P. (2015b). S kanónem na kánon aneb Kvadratura kánonu a nesamozřejmost jeho samozřejmosti II. Tvar, 17, 16-17.

Jones, P. (2003). Overcoming the obstacle course: teenage boys and reading. Teacher Librarian, 30(3), 9-14.

Kulka, J. (2008). Psychologie umění. Praha: Grada.

Lomenčík, J. (2010). Interpretácia básnického textu v stredoškolskom literárnom vzdelávaní. In E. Príhodová (Ed.), Odborová didaktika v priprave a v d'alšom vzdelávani učitel'a materinského jazyka a literatúry (s. 288-301). Ružomberok: Katolícka univerzita v Ružomberku.

Manuel, J., \& Carter, D. (2015). Current and historical perspectives on Australian teenagers' reading practises and preferences. Australian Journal of Language and Literacy, 38(2), 115-128.

Morgan, D. (1996). Focus groups. Annual Review of Sociology: Annual Reviews, 22, 129-152.

Nezkusil, V. (2004). Nástin didaktiky literárni výchovy. Praha: Pedagogická fakulta UK.

Peskin, J., Allen, G., \& Wells-Jopling, R. (2010). „The educated imagination“: applying instructional research to the teaching of symbolic interpretation of poetry. Journal of Adolescent \& Adult Literacy, 53(6), 498-507.

Radváková, V. (2015). Práce s textem na střední škole. Orbis scholae, 9(3), 87-110.

Slavík, J,. Chrz, V., Štech, S., et al. (2013). Tvorba jako zpuisob poznávání. Praha: Karolinum. Slavík, J., Janík, T., Jarníková, J., \& Tupý, J. (2014). Zkoumání a rozvíjení kvality výuky v oborových didaktikách: metodika 3A mezi teorií a praxí. Pedagogická orientace, 24(5), 721-752.

Škoda, J., Doulík, P., et al. (2010). Prekoncepce a miskoncepce v oborových didaktikách. Ústí nad Labem: Univerzita J. E. Purkyně. 
Uusen, A. (2010). Reading activities and reading preferences of the 6 th grade students of basic school in Estonia. Problems of Education in the 21st Century, 20, 135-145.

Uusen, A., \& Müürsepp, M. (2012). Gender differences in reading habits among boys and girls of basic school in Estonia. Procedia-Socialand Behavioral Sciences, 69, 1795-1804.

Vala, J. (2011). Poezie v literárni výchovè. Olomouc: Univerzita Palackého.

Vala, J. (2015). Specifika lyrické poezie jako učební úlohy. Orbis scholae, 9(3), 53-67.

Watkins, N., \& Aimonette Liang, L. (2014). The „literature“ of literature anthologies: An examination of text types. Middle Grades Research Journal, 9(2), 57-74.

Young, L. (2007). Portals into poetry: Using generative writing groups to facilitate student engagement with word art. Journal of Adolescent \& Adult Literacy, 51(1), 50-55.

Doc. Mgr. Jaroslav Vala, Ph.D.

Univerzita Palackého v Olomouci, Pedagogická fakulta, Katedra čského jazyka a literatury; e-mail: jaroslav.vala@upol.cz

VALA, J. Comenius's Writings as Reading for Pupils in Basic Schools?

Goals - The study is a response to current debate on the content and overall conception of literary education at basic (primary) schools. The main goal is to analyse the reader reception of eight different literary extracts by pupils in the ninth year of basic school, then to assess differences in their reactions and engagement with the text and to evaluate the suitability of the texts for the age-group concerned (approx. 15 years old).

Methods - In the quantitative part of the research project we used the method of semantic differential and using an assessment scale adjusted and tested by factor analysis we analysed the reader experiences of 203 respondents from the point of view of three factors: comprehensibility, evaluation and appeal. We carried out the qualitative part of the survey using focus groups. On the basis of audio recordings we identified how pupils reacted to individual texts and how they thought/spoke about them.

Results - From the reactions of the pupils it emerged that the difficult and for them incomprehensible language made it impossible for them to receive the semantic meaning of several literary works included in readers (J. W. Goethe: Faust, Comenius, The Labyrinth of the World and the Paradise of the Heart). They cannot get to the message and ideas through the text itself. The pupils expressed appreciation above all of texts that they are capable of relating to their own lives and today's world.

Conclusions - The results of the survey can serve as basic information useful for discussion on innovation of the content of teaching and its reform in the direction of the needs and capabilities of pupils. If pupils encounter texts that are within the limits of their level of understanding, we can also develop their basis of knowledge of the world, and not only in relation to literary history and theory. It is desirable and useful to influence children's reading skills and scope in the direction of higher quality, but at the same tim we must not lose contact with their basic understanding, for otherwise our teaching will lose communicative power and authenticity and will become merely formal..

Keywords: readership, reception of the text, understanding of the text, literary education, reader. 